\title{
DEGRADATION OF WATER HYACINTH (EICHHORNIA CRASSIPES) TO VERMICOMPOST THROUGH APPLICATION OF THE VERMICOMPOSTING TECHNOLOGY
}

\author{
Mercy M. Manyuchi ${ }^{1}$, Charles Mbohwa ${ }^{1}$, Edison Muzenda ${ }^{1,2}$, Trevor N. Mutusva ${ }^{3}$ \\ and Miranda Mpeta ${ }^{4}$ \\ ${ }^{l}$ Department of Operations and Quality Management, Faculty of Engineering and the Built Environment, \\ University of Johannesburg, South Africa \\ ${ }^{2}$ Department of Chemical, Materials and Metallurgical Engineering, Faculty of Engineering and Technology, \\ Botswana International University of Science and Technology, P Bag 16, Palapye, Botswana \\ ${ }^{3}$ Department of Mathematical Sciences, School of Industrial Sciences and Technology, Harare Institute of Technology, \\ Zimbabwe \\ ${ }^{4}$ Department of Environmental Engineering, Faculty of Engineering, Chinhoyi University of Technology, Zimbabwe
}

\begin{abstract}
This study focuses on the microbial degradation of water hyacinth (Eichhornia crassipes) to vermicompost as a bioconversion strategy. Water hyacinth was vermicomposted using Eisenia Fetida earthworms loaded at a rate of 150 earthworms/L over a period of 35 days. The changes in water hyacinth total organic carbon (TOC), chemical oxygen demand (COD), total nitrogen (TP), and total phosphorous (TP) and total potassium (TP) were measured using standard methods. Linear models were generated using MATLab 13.0 to describe the changes in physicochemical properties with change in vermicomposting time using the regression coefficients $\left(\mathrm{R}^{2}\right)$ values. The TOC and COD decreased significantly by $60 \%$ and $53 \%$ as the water hyacinth was converted to vermicompost. The TKN, TP and TK increased by $93 \%, 127 \%$ and $98 \%$ respectively. Linear models developed indicated $\mathrm{R}^{2}$ values of 0.9 for all the parameters.
\end{abstract}

\section{KEYWORDS}

Bioconversion, Degradation, Earthworms, Vermicompost, Water Hyacinth

\section{INTRODUCTION}

The vermicomposting technology is being used as a waste management tool (Suthar 2007; Gutie'rrez-Miceli et al. 2008). During vermicomposting, earthworms ingest biomass to expel vermicasts, which are rich in total nitrogen (TKN), phosphorous (TP), and potassium (TK) (Shrestha et al. 2011). The vermicompost produced can be used as a bio fertilizer as well as soil conditioner due to the high nutrient composition of vermicasts (Gajalakshmi et al. 2002; Bernal et al. 2009). The vermicomposting technology can be used for the management of water hyacinth, a highly lignocellulose material that contaminates water bodies (Gupta et al. 2006; Adi and Noor 2009). Vermicomposting as a microbial process breaks down the components of the water hyacinth (Eichhornia crassipes) to a bio fertilizer (Patidar et al. 2013). This study looked at the degradation of water hyacinth through vermicomposting with an emphasis on the changes in the physicochemical parameters as the vermicomposting period increased. Furthermore, models on the variations of these parameters were presented, a knowledge gap has not been addressed in the current literature.

\section{MATERIALS AND METHODS}

Water hyacinth was collected from a nearby dam (where it is an invasive species) and was pre-composted for 2 weeks in order to catalyse the vermicomposting process. The water hyacinth was mixed with cow dung in 
the ratio 10:1 to increase the presence of microorganisms in the bio waste. Eisenia Fetida earthworms were introduced as the vermicomposting inoculum with 150 earthworms/L. Vermicomposting of water hyacinth was allowed to take place for a period of 35 days after the pre- composting. The $\mathrm{pH}$ of the vermicompost was measured using a Hanna HI $99121 \mathrm{pH}$ probe. The total organic carbon (TOC) was measured using the Walkley-Black method, the total Kjeldhal nitrogen (TKN) was measured using the Kjeldhal method, total phosphorous (TP) was measured using the Olsen method and total potassium content (TK) was measured using a flame photometer. The detailed characterization of the vermicompost physicochemical were done in detail by Soobhany et al. (2017). All parameter readings were taken thrice and an average value used.

Statistical analysis was used in determining the changes in the vermicompost physicochemical characteristics trends (Chikae et al. 2006). Linear regression models were used to determine the effect of vermicomposting on the water hyacinth physicochemical properties at $95 \%$ confidence interval. Accuracy of the models was quantified through regression coefficient values $\left(\mathrm{R}^{2}\right)$. Matlab 2013's curve fitting toolbox was used for determining the polynomials as indicated by Equation 1.

$$
f(x)=p_{n} X^{n}+p_{n-1} X^{n-1}+\cdots+\cdots p_{1} X+p_{0}
$$

\section{RESULTS AND DISCUSSION}

\subsection{Water Hyacinth Physicochemical Characteristics}

The physicochemical characteristics of water hyacinth are as indicated in Table 1 . These parameters were monitored during the vermicomposting period. The pre- composting ( 2 weeks) of the water hyacinth was necessary to enhance the decomposition of the water hyacinth to vermicompost.

Table 1. Water Hyacinth Physicochemical Characteristics

\begin{tabular}{|l|l|}
\hline Parameter & Value \\
\hline Moisture content & $85.62 \pm 2.47$ \\
\hline TKN & $0.97 \pm 0.02$ \\
\hline TP & $0.45 \pm 0.04$ \\
\hline TK & $0.87 \pm 0.02$ \\
\hline TOC & $55.32 \pm 6.04$ \\
\hline Ash content & $62.01 \pm 0.71$ \\
\hline
\end{tabular}

\subsection{Effect of Vermicomposting on TOC}

TOC content in the water hyacinth significantly decreased with an increase in the vermicomposting period with an $\mathrm{R}^{2}$ value of 0.983 (Figure 1). 


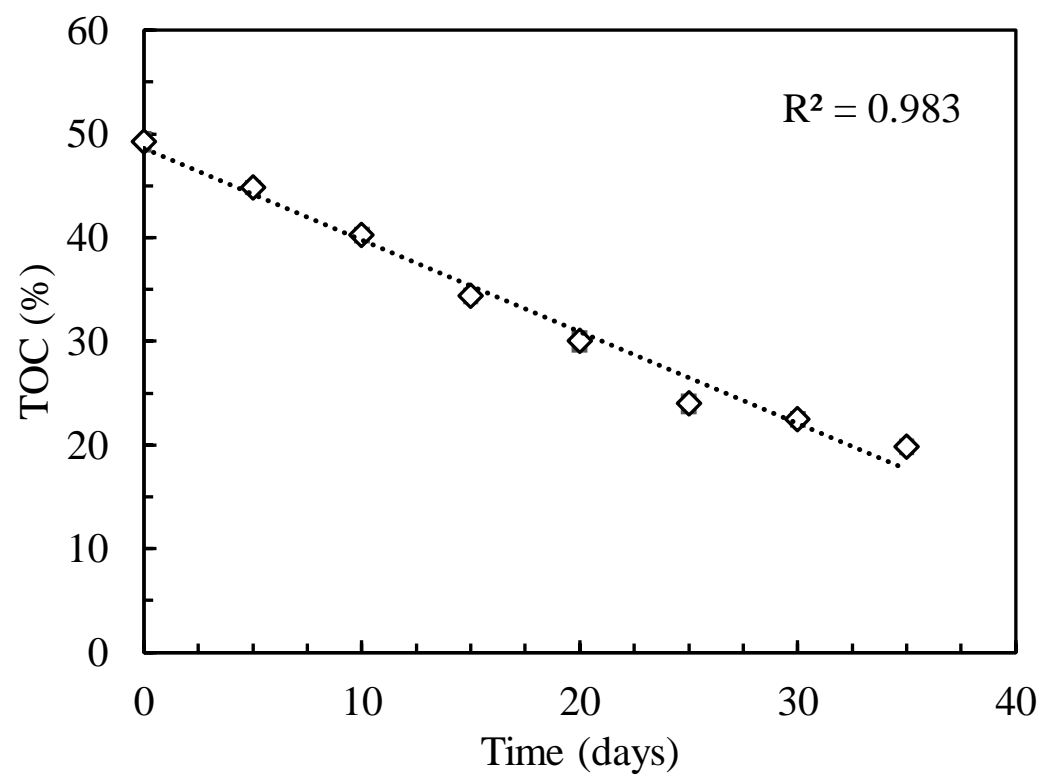

Figure 1. Effect of Vermicomposting on TOC

Vermicomposting promoted the degradation of organic compounds in the water hyacinth resulting in the observed decrease (Pullicino et al. 2007).This was seen by an overall 60\% decrease in TOC which was attributed to the decomposition of the water hyacinth by earthworms. The TOC decrease during the water hyacinth vermicomposting was modelled by a linear model with polynomial order 3 as indicated in Equation 2.

$$
\text { TOC }=0.0006598 X^{3}-0.02595 X^{2}-0.7334 X+49.23 .
$$

\subsection{Effect of Vermicomposting on COD}

COD decreased significantly, as the vermicomposting period of the water hyacinth increased, with an $\mathrm{R}^{2}$ value of 0.973 as indicated in Figure 2.

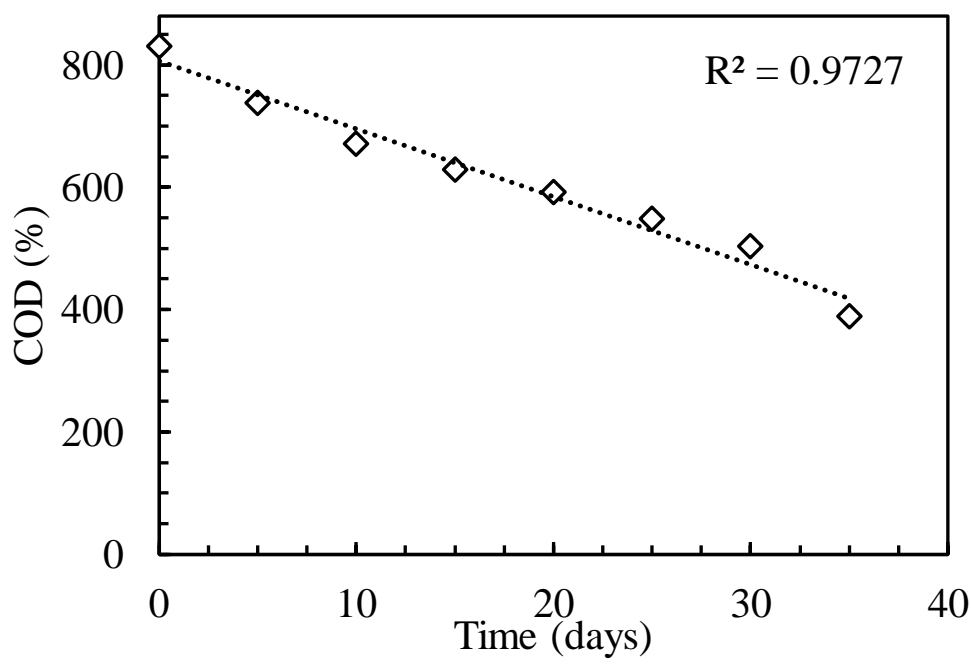

Figure 2. Effect of Vermicomposting on COD 
An overall decrease of 53\% was observed for COD as the vermicomposting period increased. This trend was attributed to the reduction in biomass present in water hyacinth (Gajalakshmi et al, 2001). The decrease in the COD followed a linear model with polynomial order 3 as indicated in Equation 3.

$$
C O D=-0.01919 X^{3}+1.012 X^{2}-24.43 X+832.7
$$

\subsection{Effect on TKN}

The TKN increased significantly with an increase in the vermicomposting period as indicated in Figure 3 with an $\mathrm{R}^{2}$ value of 0.956 .

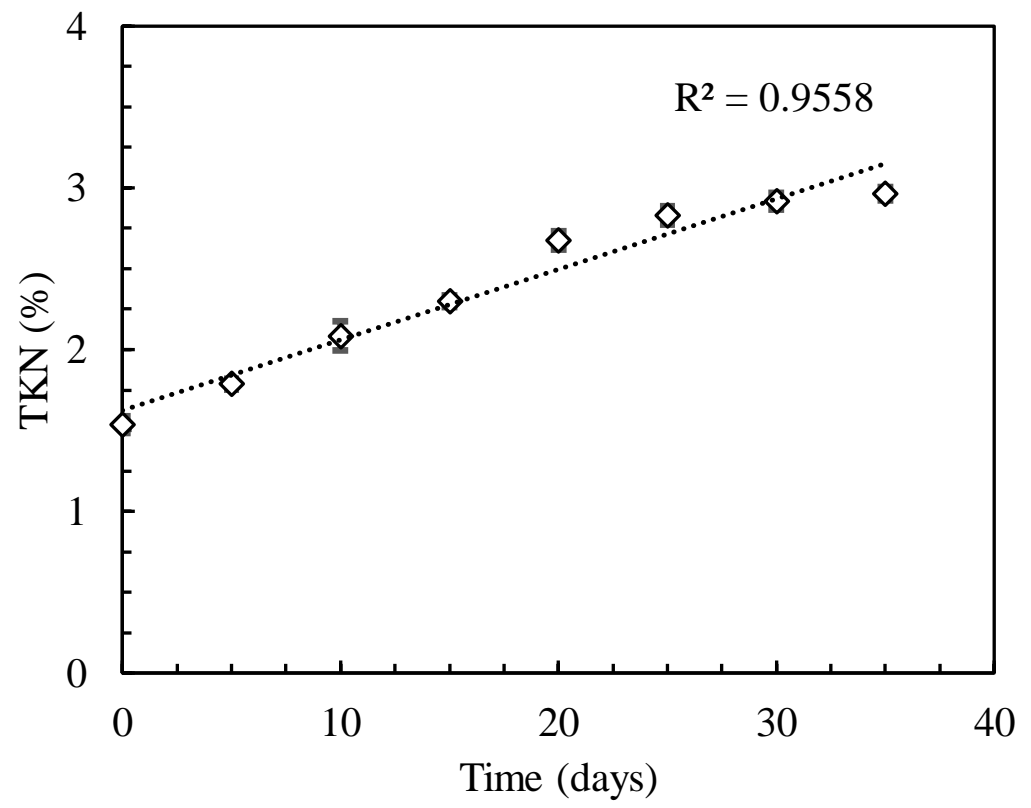

Figure 3. Effect of Vermicomposting on TKN

The increase in TKN followed a linear model with a polynomial order number 3 as indicated in Equation 4.

$$
T K N=-0.00004 .061 X^{3}+0.001322 X^{2}+0.0439 X+1.537
$$

TKN of the water hyacinth showed a $93 \%$ increase as the vermicomposting period increased and this was attributed to the mineralization of nitrogenous components during vermicomposting resulting in high TKN content. Earthworms also contributed to the high TKN content due to the release of nitrogenous waste during vermicomposting (Kaviraj 2003).

\subsection{Effect on TP}

TP increased significantly with increase in the vermicomposting period of the water hyacinth as indicated in Figure 4 with an $\mathrm{R}^{2}$ value of 0.969 . 


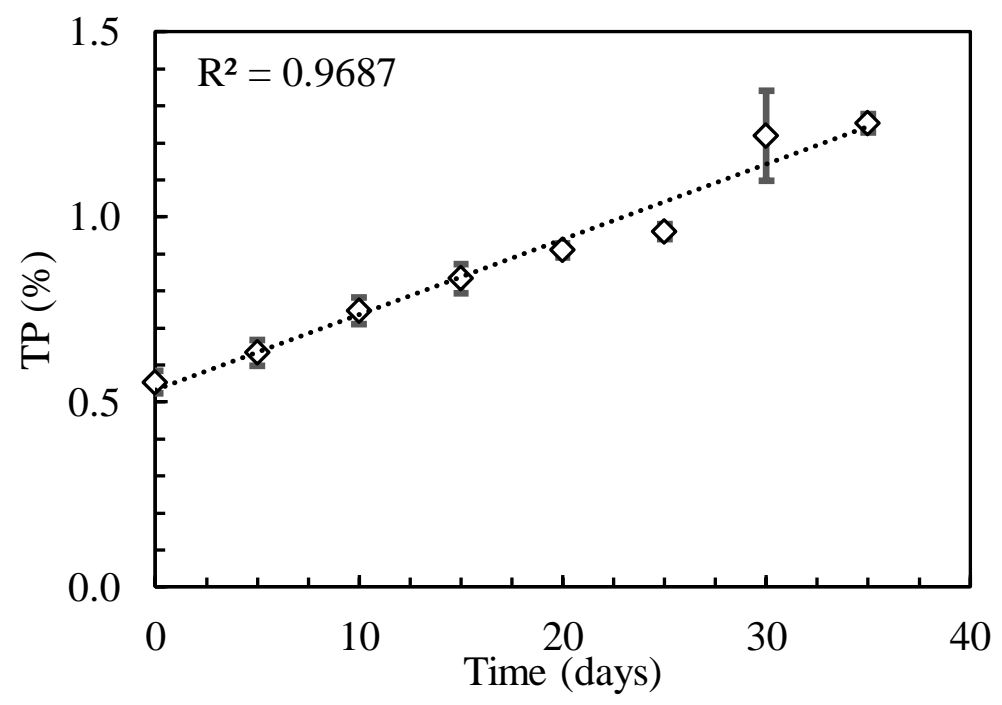

Figure 4. Effect of Vermicomposting on TP

Increase in TP with increase in vermicomposting followed a linear model with polynomial order number 3 (Equation 5). Vermicomposting of the water hyacinth resulted in a $127 \%$ increase in the TP.

$$
T P=-0.000001 .328 X^{4}+0.00009 .79 X^{3}-0.002116 X^{2}+0.03182 X+0.5437
$$

The vermicomposting process enhances nutrient availability which maybe the case in vermicomposting of water hyacinth leading to increased TP. When vermicomposting occurs, various organic acids are formed due to the decomposition of the organic waste. Furthermore, the earthworms' intestines have the ability to convert the insoluble TP to soluble form (Adhami et al. 2014).

\subsection{Effect on TK}

TK content increased significantly as vermicomposting period increased as shown in Figure 5 with an $\mathrm{R}^{2}$ value of 0.999 .

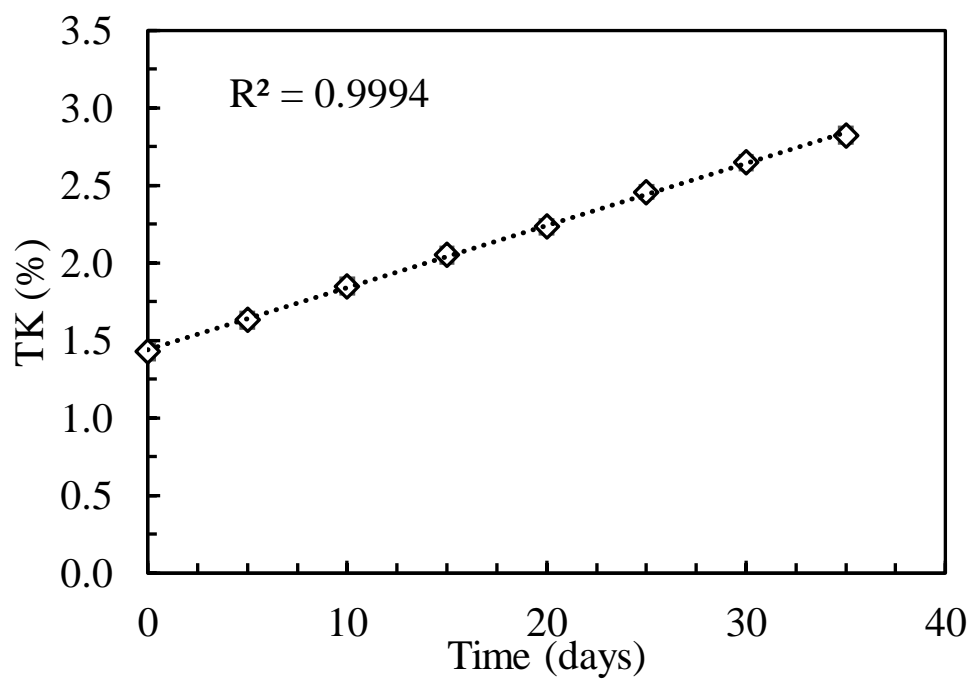

Figure 5. Effect of Vermicomposting on TK 
The increase in the TK during the vermicomposting of water hyacinth followed a linear model with polynomial order 1 as indicated in Equation 6 . The TK increased by $98 \%$ during the vermicomposting period.

$$
T K=0.04015 X+1.437
$$

The increase in the TK content was attributed to the critical role the earthworms and microbes played during the vermicomposting of water hyacinth. The production of acid by the microbes during vermicomposting potentially resulted in solubilisation of insoluble potassium hence the increase in TK (Garg et al. 2006).

\subsection{Summary of Findings}

A summary of the changes in the water hyacinth characteristics are given in Table 2.

Table 2. Summary of Water Hyacinth Vermicompost Composition

\begin{tabular}{|l|l|l|l|}
\hline Parameter & Before vermicomposting & After vermicomposting & $\%$ Change \\
\hline TOC $(\%)$ & $49.26 \pm 0.72$ & $19.84 \pm 0.49$ & $60 \%$ decrease \\
\hline COD $(\%)$ & $830.33 \pm 4.04$ & $389.33 \pm 2.52$ & $53 \%$ decrease \\
\hline TKN (\%) & $1.54 \pm 0.05$ & $2.96 \pm 0.04$ & $93 \%$ increase \\
\hline TP $(\%)$ & $0.55 \pm 0.03$ & $1.25 \pm 0.03$ & $127 \%$ increase \\
\hline TK $(\%)$ & $1.43 \pm 0.04$ & $2.82 \pm 0.04$ & $98 \%$ increase \\
\hline
\end{tabular}

In summary, the degradation of water hyacinth through vermicomposting results in a vermicompost that is rich in NPK.

\section{CONCLUSION}

Vermicomposting of water hyacinth presents an opportunity for management of lignocellulose waste to value added bio products like vermicompost. The vermicompost produced from water hyacinth was rich in TKN, TP and TK with an average composition of $2.96 \%, 1.25 \%$ and $2.82 \%$ respectively. The change in the water hyacinth parameters accurately followed linear models.

\section{REFERENCES}

Adhami, E., Hosseini, S., Owliaie, H., 2014. Forms of phosphorus of vermicompost produced from leaf compost and sheep dung enriched with rock phosphate. International Journal of Recycling of Organic Waste in Agriculture. 3, 5. https://doi.org/10.1007/s40093-014-0068-9

Adi, A. J., Noor, Z. M., 2009. Waste recycling Utilization of coffee grounds and kitchen waste in vermicomposting. Bioresour. Technol. 100, 1027-1030.

Bernal, M. P., Alburquerque, J. A., Moral, R., 2009. Composting of animal manures and chemical criteria for compost maturity assessment. A Review. Bioresour. Technol. 100, 5444-5453. 
Chikae, M., Ikeda, R., Kerman, K., Morita, Y., Tamiya, E., 2006. Estimation of maturity of compost from food wastes and agro-residues by multiple regression analysis. Bioresour.Technol. 97, 1979-1985.

Gajalakshmi, S., Ramasamy, E. V., Abbasi, S. A., 2002. High-rate composting-vermicomposting of water hyacinth [Eichhornia crassipes (Mart.) Solms]. Bioresour. Technol. 83, 235-239.

Gajalakshmi, S., Ramasamy, E. V., Abbasi, S. A., 2001. Potential of two epigeic and two anecic earthworm species in vermicomposting of water hyacinth. Bioresour. Technol. 76, 177-181.

Garg, V. K., Yadav, Y. K., Sheoran, A. S., Kaushik, P., 2006. Livestocks excreta management through vermicomposting using an epigeic earthworm Eisenia Fetida. Environmentalist, 26, 269-276.

Gupta, R., Mutiyar, P. K., Rawat, N. K., Saini, M. S., Gupta, V. K. 2006. Development of a water hyacinth based vermireactor using an epigeic earthworm Eisenia foetida, Bioresour. Technol. 98, 13, 2605-2610.

Gutie'rrez-Miceli, F. A., Moguel-Zamudio, B., Abud-Archila, M., Gutie'rrez-Oliva VF, Dendooven L. Sheep manure vermicompost supplemented with a native diazotrophic bacteria and mycorrhizas for maize cultivation. Bio resource Technol 2008; 99: 7020-7026.

Kaviraj, S. S., 2003. Municipal solid waste management through vermicomposting employing exotic and local species of earthworms. Bioresour. Technol., 90, 169-173.

Patidar, A., Gupta, R., Tiwari, A., 2013. Potential of Microbial Inoculated Water Hyacinth Amended Thermophilic Composting and Vermicomposting in Biodegradation of Agro-Industrial Waste. J Bioremed Biodeg. 4, 191. doi:10.4172/2155-6199.1000191.

Pullicino, S. D., Erriquens, G. F., Gigliotti, G., 2007. Changes in the chemical characteristics of water-extractable organic matter during composting and their influence on compost stability and maturity. Bioresour. Technol. 98, 1822-1831.

Shrestha, K., Shrestha, P. M., Adetutu, E., Walsh, K. B., Harrower, K. M., Ball, A. S., Midmore, D. J., 2011. Changes in microbial and nutrient composition associated with rumen content compost incubation. Bio resource. Technol. 102, $3848-3854$.

Soobhany, N., Gunasee, S., Rago, Y. P., Joyram, H., Raghoo, P., Mohee, R., Garg, V. K., 2017. Spectroscopic, thermo gravimetric and structural characterization analyses for comparing municipal solid waste composts and vermicomposts stability and maturity. Bioresour. Technol. 236, 11-19.

Suthar, S., 2007. Nutrient changes and biodynamics of epiganic earthworm Perionyx excavatus (Perrier) during recycling of some agriculture wastes. Bioresour. Technol. 98, 1608-1614. 